\title{
Audit Procedures and Responsibilities on Audit Decisions: An Examination for Kenya
}

\author{
Joshua W. Chesoli* and Eliud Kerio Long'acha**
}

\begin{abstract}
The purpose of this study is to examine how internal audit procedures and responsibility perceptions of the auditors impact the audit decisions of independent external auditors. The questions of the research are answered by the certified public accountants (CPA) operating in Kenya and the establishments that audit companies independently. The results of the study show that the procedural efficiency of internal auditors in auditing and their taking responsibility have a positive impact on the decisions of independent external auditors. Another result of the study was that in the absence of internal audit elements in the company or in the case that internal auditors do not function properly, the audit result of the independent auditor will be more ineffective. In this respect, in order to get objective and reliable data from the independent external auditors, internal procedures should be streamlined and internal auditors should be willing to cooperate with external auditors more.
\end{abstract}

Keywords: Independent auditing, Internal procedure, Responsibility, Kenya, Auditing decisions.

\subsection{Introduction}

The expectation, particularly from the independent auditors, is that the auditing activities should be done objectively according to the written regulations on the one hand, and according to ethical values and with responsibility on the other. The more the independent auditor takes these factors into consideration in his/her report, the more useful the results will be. This study does not only look into the effects of internal audit procedures on the independent audit but also examines the impact of the responsibilities of the auditors on the independent audit decisions.

*Lecturer, Mount Kenya University, Kenya.

** Mount Kenya University, Kenya. 
Various studies have been made on internal audits. These studies were either on auditor responsibilities in internal audit (Liu et al. 1997) or internal relationship between internal audit and senior management (Sarens and De Beelde2006). The results of these studies revealed that the success in internal audit can be improved with the support of the executives. Van Peursem(2004) studied how internal auditors perceived their jobs and whether auditors faced role conflicts or not. Kerler III et al. (2008) measured and examined the effect of trust on auditors' decisions; Rasmussen and Windsor (2003) discusses the concerns and fears related to inventory manipulation, De Smet et al. (2011) examined the functionality of internal audit and Johnson (1982) looked into internal audit activities and the sufficiency of business management. When literature was reviewed, no study was found on internal auditors' commitment to internal procedures as well as on the direct impact of their responsibilities on the independent auditor decisions. Thus, the hypothesis of this study was developed.

First of all, when we look into the definitions of internal audit, we see that there are different definitions of the term internal audit. The Institute of Internal Auditors (The IIA) attempts to better understand the expanding scope of internal auditing practice throughout the world (Hass et al. 2006). The definition given by this institute is as follows: "Internal auditing is an independent, objective assurance and consulting activity designed to add value and improve an organization's operations. It helps an organization accomplish its objectives by bringing a systematic, disciplined approach to evaluate and improve the effectiveness of risk management, control, and governance process".

Internal auditing is the activity of auditing the financial statements of a business and this activity is closely related with the management performance. Internal auditing is an essential activity to test the efficiency of the business governance (Johnson 1982). The people who realise this activity are the internal auditors. Sawyer (1988) describes internal auditors as: "Internal auditors are employees of an organization whose job is to review company operations to determine whether acceptable policies and procedures are followed, whether established standards are met, whether resources are used efficiently, and whether the organization's objectives are being achieved".

In their study, Cooper et al. (2006) and Hass et al. (2006) state that internal auditing differs greatly all around the world. These differences in internal auditing, as De Smet et al. (2011) indicates, do not prevent internal audit function (IAF) to lie at the very heart of corporate governance system because accountants and auditors play a decisive role in general financial auditing (Shih et al. 2006). The job of the auditor is to report the financial structure and both normal and abnormal processes to the owner(s) of the company (Porter. 1997). However, to get the expected benefit from the auditing activities, these activities have to be over a certain quality level. The quality of audits is 
dependent on the technical skills of audit teams and organizational values (Sikka et al. 2009). Social responsibility and social benefit should also be considered importantly as well as quality. Auditors also face various conflicts during these audit activities. These are legal responsibilities and moral values. Goldman and Barlev (1974) state that auditors are frequently in conflict with moral values when preparing and presenting financial statements. As Hasselager et al. (1998) states that auditor, for the benefit of the society, behaves fair and independent in their decisions, without being effected by any interest group.

Our study focuses on how internal audit procedures and auditor responsibilities are perceived by an independent auditor. We look at the kind of contributions that internal audit procedures and the audit responsibilities of internal auditors provide to the audit activities of independent auditors. This study will provide two essential contributions to the accounting literature. First of all, how internal audit procedures will affect the independent auditor decisions will be researched and secondly, the kind of contributions that the responsibility of internal auditors provide to external auditors will be examined. In existing studies, it is mostly the independence of the internal auditor that is discussed. The independence of the external auditor, on the other hand, is also considered important. These studies on auditing are more centered on developed economies. This study, which intends to contribute to existing studies or to introduce any differences, if exists, is done in Kenya, which is both a developing country and a candidate to be an important financial center. While various theoretical studies are conducted on internal audit function and responsibility and audit risks in Europe and the USA, there are not sufficient studies in the field for Kenya. This study aims to make a scientific contribution by comparing previous research results. The rest of the paper is structured as follows: the second section discusses the conceptual framework. In this section, internal audit and procedures, corporate responsibility approaches and the perception of external audit are mentioned. The third section deals with sample selection and research methodology. In the fourth section, the results of the study are presented and discussed; the fifth section concludes.

\subsection{Conceptual Framework}

\subsection{Internal audit procedures}

The roles of internal and external auditors are still a matter of debate today (Alleyne and Howard. 2005). As Dorweiler (2004) describes, the function of internal audit is to examine all factors that will enable the prevention of financial malfunctions and to detect false financial reports early. In this sense, the importance of the role of 
internal audit department of a company should not be underestimated (Liu et al. 1997). As Lousteau and Reid (2003) state internal control system has two purposes: one is to operate in areas that board of management determines and second is to be independent. According to Sarens and De Beelde (2006), internal audit helps to enhance the quality of internal and external reporting. Flesher (1996), on the other hand, says if companies do not have a modern internal audit mechanism, they will eventually need such a mechanism and even set up this system.

Audit trajectory can be considered as a process including seven different stages (Akkerman et al. 2008). Stages of the audit procedure include:

a) Orientation to the audit procedure,

b) Orientation to the study Auditee arranges the logistics for the auditor and explains the audit trail,

c) Determination of the auditability of the study,

d) Negotiation of the contract Auditee and auditor establish timeline,

e) Assessment Based on the audit trail,

f) Renegotiation Auditor presents findings and discusses discrepancies

g) Final auditor report Auditor writes a substantiated assessment on the trustworthiness of the study".

As Mc Enroe et al. (2005) states "In 1939, the Committee on Auditing Procedure (CAuP) was established by the American Institute of Accountants, predecessor to the American Institute of Certified Public Accountants (AICPA) and The Auditing Standards Executive Committee (AudSEC) replaced the CAuP in 1972 (Mc Enroe et al. 2005), and evolved into the present organization, the Auditing Standards Board (ASB) in 1978 ".

In previous studies, it was stated that the auditor report may lead to new discussions or new audit procedures (Akkerman et al. 2008), that internal audit department employees could only spare $5 \%$ of their time for external auditors (Wallace, 1984) and that internal audit process did not satisfy those accountants engaged in management accounting (Flesher and Zanzig, 2000). Despite all these audit deficiencies, audit procedures shall be prepared in an apprehensible way for all accountants and external auditors and shall be prepared as a form. During auditing internal auditors are often under pressure to produce quality work (Brown and Mendenhall, 1995). Contrary to external auditors, the independence of internal auditors is identified as most important (Flesher and Zanzig. 2000).Lack of procedures in collecting quality information effects the analysis of financial information (Akkerman et al. 2008). The audit procedure is specifically related to who will make the audit. The audit procedure preparation work and activity begin with pre-orientation and discussion. Following that, the auditor should examine all 
materials provided to him in detail (Akkerman et al. 2008). Preparations should be made beforehand to make the audit. In this preparation, the procedure to be followed, material to be used and how findings will be used, should be determined; and audit procedures which will pave the way for quality decisions should be applied (Akkerman et al. 2008). Internal audit executives can estimate data regarding the procedures and assets of the company better than the external auditors (Larkin. 2000). Since the internal auditor is closer to the administration of the company, s/he can discuss the deficiencies with executives and take necessary measures to inform the external auditors (Gliem. 1994). Lack of information and disruptions occurring due to this, impact the report of the external auditor (Larkin. 2000). On the other hand, internal audit unit prepares worksheets and programmes, flow charts and reports and present them to the external auditors use (Sarens and De Beelde, 2006). Audit procedures should not be far too much. The excess of audit procedures delays becoming aware of the internal mistakes (Kerler III and William, 2008). However, as Uecker et al. (1981) states, internal auditor is "strong" and "active" within the company. Audit procedures impact the responsibility of the auditor (Arel et al. 2005). Internal auditors, who are strong and active in internal audit, are effective in the financial decisions of independent auditors. Thus;

H1: Increasing the perceived "procedure" of internal auditing activities increases the efficiency of independent audit decisions.

\subsection{Responsibility}

Responsibility is a frequently emphasised concept in audit literature. Along with such concepts as company responsibilities, social responsibilities, environmental responsibilities, auditor responsibilities are discussed as well. In this study, the responsibility of internal auditor is discussed. In small businesses, internal auditors have responsibilities in auditing financial statements and risk management (Van Peursem, 2004). Although determining fraud which might occur in the company is not in the scope of internal auditors' responsibility, it is the necessity of a responsible behaviour for internal auditors to have enough background knowledge to determine such fraud indicators (Flesher and Zanzig. 2000). Martens and McEnroe (2001) analysed the events leading and said that the SAS was to clarify the auditors' responsibilities in the area of fraud detection. As stated by Liu et al. (1997), in their research, audit committee can help the board of management by bearing audit responsibility and by determining the right company activities, policy implementation and performance measures. Besides, by doing this, internal auditors might contribute to external auditor report to reflect the truth. Internal auditors support external auditors to do their responsibilities (Flesher and Zanzig. 2000). Internal auditors can share information with top management more easily; 
the same thing is not valid for external auditors. As Uecker et al. (1981) states independent auditors cannot directly contact with executives regarding their responsibilities and informing the management. When we consider that the reports of external auditors are more independent compared to internal auditors, we can say that internal auditors shoulder an important responsibility. As stated above, this is because internal auditors, who provide an easier information flow with the top management, can serve as an intermediary for external auditors. This way, also the top management will be informed about internal deficiencies. Besides, when internal auditors bear this responsible behaviour financial analysis will prove more effective results. Thus;

H2: Increasing the perceived "responsibility" of internal auditing activities, increases the efficiency of internal audit procedures.

H3: Increasing the perceived "responsibility" of internal auditor activity increases the efficiency of independent audit decisions.

\subsection{External Audit decisions}

INTOSAI GOV 9150 standard determines the outline of coordination and cooperation between external and internal audit and expands it globally (http://INTOSAI.org, 2010). This Standard also aims to help auditors act together in their decisions and behave independently. There are various studies on the independency of the auditor decisions (e.g. Arnold, Barnardi and Neidermeyer . 1999: Mc Enroe. 2003: Flesher and Zanzig. 2000: Hass et al. 2006 ). When preparing and interpreting financial statements, the auditor should not be under the pressure of any interest groups. The same thing should be valid for both the internal and external auditors. External auditors, who work in coordination with internal audit unit, increase the coordination of audit activity through information exchange (Sarens and De Beelde, 2006). External audit function provides an independent view for the company, which enables the management to make detailed examination, internal control and move according to laws and legislations (Gramling et al. 2004). External audit is a methodical and systematic validity method to follow accounting records and to reach the right audit decisions (Miller, 1997). And external audit also directs accountants to behave honest and responsible. As Ashton et al. (1989) states accountability is important in the auditing environment because an auditor is required to document, justify, and be responsible for his or her decisions. As stated by Rasmussen and Windsor(2003), while independent auditors are doing a profitable business and preparing financial statements for company managements on the one hand, they behave in professional standards by carrying out these activities on the other. They are also responsible to look after public interests. Ethical tendencies of the auditors impact the independency of the audit (Ponemon and Gabhart, 1990). Groups that use the 
financial statements (e.g. shareholders, investors, future investors, unions, retirees, future retirees, financial institutions, government bodies etc.) believe that the remarks of the auditors are Professional and reliable (Rasmussen and Windsor. 2003). If those auditors loose the public confidence, more strictsanctions and regulations should be put in order for those people to behave in accordance with the standards(Warming and Rasmussen, 1996). As Sutton (2002) sets forth, company scandals rest on mass manipulations. In such situations, both domestic and international companies might face serious problems. Although there is a distinction between internal and external audit, both groups do the same job in essence and they are continuously in contact with each other. Mutual cooperation, understanding and information exchange will save time for the company and decrease the cost of audit (Liu et al. 1997).

\subsection{Sample Selection and Research Methodology}

To test and generalise the hypothesis, a questionnaire was applied on certified public accountants and audit companies active in Nairobi and Nakuru regions, the most densely populated regions of Kenya. This study analyses the relationship of the certified public accountants, who certify the financial statements of companies, and the companies that audit companies through independent auditing with the internal auditors during the audit process. We then examine those 'behaviours' of the internal auditors which can provide positive contributions to the efficiency of the audit. To do this, tested variables that effect independent audit in international literature is used and hypothesised. Special importance is attached for companies on which the study was applied, to have an audit authorisation. When determining the companies, CPA (K) (Certified Public Accountants of Kenya) lists were used and company addresses found. The companies chosen are mostly located in the west part of the country. Questionnaire method is chosen as the data collection method. Data collection through questionnaire is a widely used method both in our country and in the world. When arranging the questions of the questionnaire, first of all, translations were made from English to Turkish. The scales were carefully prepared with internationally recognised questions, whose validity and reliability are tested. In doing that, scales in the articles published in international publications were used. Test questionnaires were made and the incomprehensible questions, at the end of the test, were rewritten and the questionnaire was finalized. Since return rate of the questionnaires by post is low and takes a long time, this causes problems. Thus, collecting questionnaires by post was not chosen as questionnaire collecting method. 245 questionnaires were sent to companies by e-mail and 325 questionnaires were applied face to face. Face to face meetings increased the 
rate of feedback. Some of the questionnaires were applied face to face by the summerintern. Each intern implementer was given 5 questionnaires. These questionnaires were answered by the executives and owners of the companies. When reviewing the questionnaires 132, were declared null and void as they were randomly answered. As a result, there were 438 usable questionnaires in this study and the rate of feedback is $77 \%$. In all parts of the questionnaire, five point likert scale is used.

The scales in the questionnaire of the study are measured in the following way: internal procedure (INTPRO) is measured with 3 questions, responsibility (RESPON) is measured with 4 questions, audit decision (AUDDE) is measured with 3 questions. And the questions were adapted from Kerler III et al. (2008) and Colley et al. (1997). All variables were measured in the following way: 1-strongly disagree, 5- strongly agree. In analysing the data SPSS 18.0 statistics programme is used.

\subsection{Results and Analysis}

The preliminary results and main findings of the study are presented below. As a result of the factor analysis, Cronbachs' alpha reliability test was found to be sufficiently high (lowest 53\%) (Table 1). Besides, the summary statistics such as average and standard deviations of variables have been presented (Table 2).

Table 1: Factor Loading Scores for the Items

\begin{tabular}{|l|c|}
\hline Measurement items & Cronbachs' alpha \\
\hline 1- Internal Procedure & .827 \\
\hline 2- Responsibility & .671 \\
\hline 3- Audit decisions & .633 \\
\hline Declared total variance & $\% 76$ \\
\hline
\end{tabular}

Note: Method of Analysis: Principal Components Analysis. Rotation Method: Varimax with Kaiser Normalization. Rotation was concluded in 4 iterations.

Table 2: Mean, Standard Deviation and Pearson Correlation of Variables

\begin{tabular}{|l|l|l|c|c|c|}
\hline Measure & Mean & S.D. & INTPRO & RESPON & AUDDE \\
\hline Internal Procedure & 4.06 & 0.887 & - & & \\
\hline Responsibility & 3.50 & 0.864 & $0.364 * *$ & - & \\
\hline Audit decisions & 4.11 & 0.817 & $0.706 * *$ &, $505 * *$ & \\
\hline
\end{tabular}

To see the factorial distribution of the three variables including the characteristics of external audit company managers and their burden, a series of factor 
analysis are made and the following results are obtained; declared total variance is $76.0 \%$. In the Cronbachs' alpha, reliability test applied after validity of the scales was crosschecked, independent variables had an impact over 0.60 on the coefficients. Accordingly Internal Procedure is 0.827 and Responsibility is 0.671 .These values are above the 0,60 value stated by Bagozzi and Yi (1988). Factor distribution, loading and reliability analysis results are shown in Table 1 . The factor loading of audit decision, which is the dependent variable, is 0.633 . It is seen that all these factor loadings are loaded on relevant variables satisfactorily. In the analysis in Table 2, relations between the variables are tested and all variables were fgound to be significantly correlated to each other.

The theoretical model of the study is tested using a single-stage hierarchical regression model and the results are shown in Table 3. $\mathrm{R}^{2}$ value of the model, where audit decision is the dependent variable, is found to be 0.569 and $\mathrm{F}$ value is found to be $105.750 * *$. It can be said that this regression equation is significant. Accordingly, it is seen that 'internal procedure' $(\beta=0.27)$ impacted external auditor decisions positively at $1 \%$ significance level. The other variable, which is 'responsibility', had a positive contribution on external auditor decisions at a $1 \%$ significance level $(\beta=0.57)$. This significant relation shows that auditors place emphasis on responsibility. In line with these results, we see that the hypotheses are accepted. The results of the Path Analysis are given in Figure 1.

Table 3: Regressions Results

\begin{tabular}{|c|c|c|c|}
\hline \multirow[t]{2}{*}{ Independent Variables } & \multicolumn{2}{|c|}{ Standardized Coefficients } & \multirow[t]{2}{*}{ Dependent Variable } \\
\hline & $\beta \mathbf{t}$ & Sig. & \\
\hline Internal Procedure & 0.274 & 0.000 & \multirow[t]{2}{*}{ Audit decisions } \\
\hline Responsibility & 0.572 & 0.000 & \\
\hline $\mathrm{R}^{2}: 0,569 ; \mathrm{F}: 105,750^{* *}$ & & & \\
\hline
\end{tabular}

\subsection{Findings}

This study aimed to test the company audit procedures, an important element of auditing activity, the responsibilities of auditors and their impacts on the decisions of independent auditor. As it is known, since international capital movement has become easier in this globalising world, auditing activities came into prominence. As Atkinson (1946) says, modern internal audit both satisfies the needs of the administration and is 
an improvement that protects the rights of investors, which is one of the objectives of external audit. Common objectives of both internal and external auditors during the auditing increase the efficiency of the audit. To provide efficiency of the audit both the auditor and auditee should make a consensus (Akkerman et al. 2008).

Figure 1: Path Analysis Results

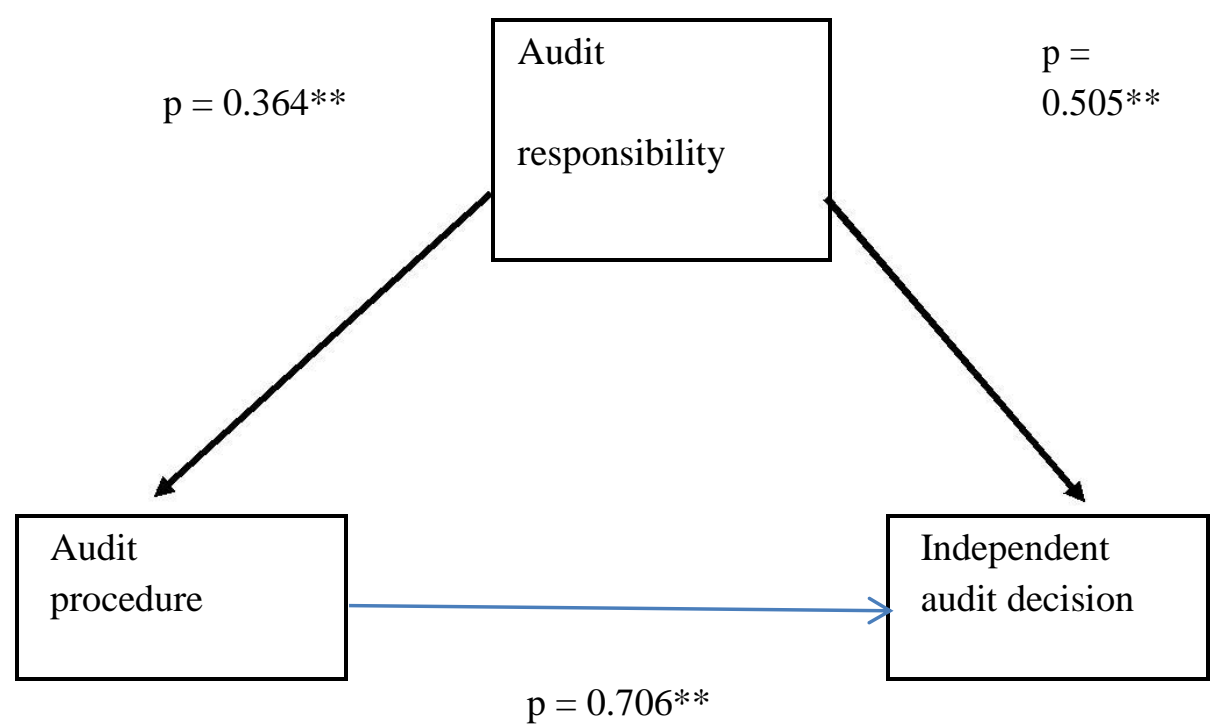

First of all, as part of internal auditor organisation, fraud behaviours that might occur should be determined (Alleyne and Howard. 2005). Then, as part of internal control system, financial reports should be prepared independently (Alleyne and Howard. 2005).External auditor should be able to make the audit relying on these reports and data. In this study, how external audit, audit procedures in internal audit and auditors' sense of responsibility will affect the audit decisions of independent external auditor is researched. The findings of the study show that the procedural efficiency of internal auditors in auditing and their bearing responsibility have provide positive results on the independent external auditor decisions. Unless internal auditors are employed in a business, expected benefits will not be obtained. This is because the external auditor will have difficulty in reaching internal resources. Thus, companies should employ internal auditors and these auditors should make information exchange with independent auditors. An internal auditor should cooperate with external auditor for account confirmation (Janvrin et al. 2010). Another result of this study is that in case internal audit elements do not exist or in the event that internal auditors do not do their job 
properly, this will make the result of the independent auditor's audit ineffective. The sense of audit activities for both parties should also be considered as well as the importance of internal auditors in providing procedural comprehensibility and ease for external auditors. In other words, they should be responsible in their behaviour. They should be objective in their decisions and should cooperate. In this sense, to get the objective and reliable data from the independent external audit, internal procedures should be made comprehensible and internal auditors should be more enthusiastic to work with external auditors. Audit activities are serious costs for companies. In this sense, Kinney (1986) says companies can improve their audit quality and decrease their experience costs by adapting to SASs. Kerler III and William (2008) emphasise in their study that SAS No. 99 states that auditors "should conduct the engagement with a mindset that recognizes the possibility that a material misstatement due to fraud could be present, regardless of any past experience with the entity and regardless of the auditor's belief about management's honesty and integrity"' (AICPA. 2002, paragraph 13, p. 10). External auditors also have responsibilities in increasing the audit quality and decreasing the costs. External auditor should accelerate the audit process by relying on internal auditors and their data; and should provide reliable data for financial statement implementations. This is because people making transactions in financial markets pay a lot of importance to the reliability of financial statements. The professionalism of the people preparing these statements proves positive results in disclosure. As Rasmussen and Windsor (2003) put it, the professional auditor must provide a fair and independent opinion about the veracity of organisational financial statements to the public.

\subsection{Conclusion}

This study looks into how the behaviour of internal auditors impact the decisions of external auditors. Procedural readiness and sense of responsibility of the internal auditor will improve the efficiency of external audit. There are various elements that affect the report of the independent external auditor. The ease and period in reaching incompany information, the process of reaching information-being short or long, and the opinions of internal auditors about the external auditors affect the benefit expected from the financial audit. Thus, behavioural states of internal auditors should be analysed as earlier studies state that internal auditors spare a limited time for external auditors and that the auditor report may lead to a new negotiation or new audit procedures (Akkerman et al. 2008; Wallace, 1984; Flesher and Zanzig. 2000). On the other hand, it is also stated that internal audit processes do not satisfy accountants dealing with management accounting. In this respect, this study is designed to learn the opinions of Kenyan 
auditors and accountants and to contribute to the literature. This study is limited to that of external auditors 'perspectives. Thus, it will be helpful to make research on how the audit activity procedures and auditor responsibilities are perceived by internal auditors. A comparison of internal and external auditors regarding audit procedures and sense of responsibility can be made and common conclusions can be drawn. However, as Mande and Son (2011) state, audit delays often occur when there are concerns about poor internal controls and clients' lack of attention to the external audit. Delays that might occur in audit generally arise as a result of auditor-client disagreements and accounting record problems (Mande and Son, 2011). In such cases, it is not possible to get the expected efficient results from the independent auditor. As Mautzand Sharaf (1961) and Hansen (1990) state, to increase the efficiency of internal audit, auditors' judgements have to be fair, objective and independent.

On the other hand, internal audit should be restructured as an important tool for the company to protect itself (Liu et al. 1997). If the auditor is convinced in the fairness of the company and in the reliability of internal procedures, these might impact the audit decisions of the independent auditor and the quality of the audit positively (Kerler III and William, 2008).This study has its limitations as other studies. The most important limitation is the discussion of the variables. As mentioned above, both internal audit procedure and the auditor responsibility were discussed with different independent variables in previous studies and the impact of these factors on the decisions of independent auditors were tested on Kenyan auditors. To make a generalization, if the same study is applied on other nations and the same results are obtained, the reliability of the study will improve. Besides, another limiting factor is that most Kenyan independent audit companies are newly established institutions. It is also a limiting factor that they are at the bottom of the ladder in terms of professionalism. Despite all these limitations, the high number of auditors, public accountants and financial advisors participating in this study and face-to-face implementation of the questionnaires make the results of the study reliable. To make generalizations, it would be helpful if researchers look from the perspectives of internal auditors as well. Of course, an efficient external audit cannot be limited with internal procedure and the responsibility of internal auditor. If other factors that impact independent audit (such as audit risk, corporate responsibility, auditor dependence) are included in implementation, the results will contribute to generalization.

\section{References}

Akkerman S, Admiral W. F,Brekelmans M,Oost. H. 2008. Auditing quality of research in social sciences. Quality \& Quantity, 42:257-274. 
Alleyne P, \& Howard, Michael. (2005). An exploratory study of auditors' responsibility for fraud detection in Barbados. Managerial Auditing Journal, 20(3): 284-303.

American Institute of Certified Public Accountants (AICPA) (2002).Consideration of Fraud in a Financial Statement Audit. Statement on Auditing Standards No. 99 (AICPA, New York).

Arel B, Brody RG., \& Pany, K. (2005). Audit firm rotation and audit quality. The CPA Journal, 5, 36-9.

Arens, A., Elder, R. \& Beasley, M. (2003). Auditing and Assurance Services: An Integrated Approach. 9th ed., Prentice-Hall, Englewood Cliffs, NJ.

Arnold, D., F. R. A. Bernardi., \& Neidermeyer, P. E. (1999). The effect of independence on decisions concerning additional audit work: A European perspective'. Auditing: A Journal of Practice \& Theory, 18(Supplement), 45-67.

Ashton, R. H., Kleinmuntz., D. N. Sullivan., J. B. \& Tomassini, L. A. (1989). Audit Decision Making', in I. Soloman and A. R. Abdel-Khalik (eds.). Research Opportunities in Auditing: The Second Decade (Auditing Section,American Accounting Association), pp. 95-132.

Atkinson, Curtist. (1946). Significant Contributions of Modern Internal Auditing to Management. The Accounting Review, 2(2).

Brown, D., Mendenhall, S. (1995). Stress and components of the internal auditor's job. Internal Auditing, 10(Winter): 31-9.

Burnaby, P. A., Abdolmohammadi, Mohammad. Hass, S. Sarens, G. \& Allegrini, M. (2009). Usage of internal auditing standards by companies in the United States and select European countries. Managerial Auditing Journal, 24: 835-860.

Cooper, B.J. Leung, P. \&Wong, G. (2006). The Asia Pacific literature review on internal auditing. Managerial Auditing Journal, 21(8): 822-34.

Colley, Ron., Mulekar, Madhuri, S., Segal, Mark A., Volkan, Ara G., Coarsey, Richard. (1997). Current status of accountant liability: audit practice. Impact Managerial Auditing Journal, 12(7), 343-353. 
De Smet, Dieter.,\& Mention, Anne-Laure. (2011). Improving auditor effectiveness in assessing KYC/AML practices Case study in a Luxembourgish context. Managerial Auditing Journal, 26(2): 182-203.

Flesher, D.L. (1996). Internal Auditing: Standards and Practices, The Institute of Internal Auditors, Altamonte Springs, FL.

Flesher, Dale L. Zanzig., \& Jeffrey S. (2000). Management accountants express a desire for change in the functioning of internal auditing. Managerial Auditing Journal, 15/7, 331-337.

Gliem, Irvin N. (1994). CIA Review (Gliem Publications, Inc, Gainesville, FL).

Goldman, A., \& Barlev, B. (1974). The auditor-firm conflict of interests: Its implications for independence. The Accounting Review (October): 707-718.

Gramling, A.A. Maletta, M.J. Schneider, A. \& Church, B.K. (2004). The role of the internal audit function in corporate governance: A synthesis of the extant internal auditing literature and directions for future research. Journal of Accounting Literature, 23: 194-244.

Hass, S. Abdolmohammadi, M.J.,\& Burnaby, P. (2006). The Americas literature review on internal auditing. Managerial Auditing Journal, 21(8): 835-44.

The IIA. (2004). The Professional Practices Framework. The Institute of Internal Auditors Research Foundation, Altamonte Springs, FL.

Janvrin, Diane., Caster, Paul., \& Elder, Randy. (2010). Enforcement release evidence on the audit confirmation process: Implications for standard setters. Research in Accounting Regulation, 22: 1-17.

Johnson, T.J. (1982). The state and the professions: peculiarities of the British. in Giddens, A.and Mackenzie, G. (Eds), Social Class and the Division of the Labour, Cambridge University Press, Cambridge, 186-208.

Kerler III, William, Killough, A. \& Larry N. (2008). The effects of satisfaction with a client's management during a prior audit engagement, trust, and moral reasoning on auditors' perceived risk of management fraud. Journal of Business Ethics, 85:109-136. 
32 | FOCUS: Journal of International Business, Volume 2, Issue 2

Kinney, W. (1986). Audit technology and preferences for auditing standards. Journal of Accounting and Economics,(March): 73-89.

Larkin, Joseph M. (2000). The ability of internal auditors to identify ethical dilemmas. Journal of Business Ethics, 23: 401-409.

Liu, Jonathan., Woo, Hong Seng, \& Boakye-Bonsu, Victor. (1997). Developing internal auditing procedures in UK organizations using a benchmarking approach. Managerial Auditing Journal, 12/9, 464-478.

Lousteau, C.L. \& Reid, M.E. (2003). Internal control systems for auditor independence. The CPA Journal, January: 37-40.

Mande, Vivek. \& Son, Myungsoo. (2011). Do audit delays affect client retention? Managerial Auditing Journal, 26: 32-50.

Martens, S., \& McEnroe, J. (1998). Interprofessional conflict, accommodation and the flow of capital: The ASB vs. the securities industry and its lawyers. Accounting, Organizations and Society, 23(4): 361-376.

Mautz, R. K. \& Sharaf, H. A. (1961). The Philosophy of Auditing. American Accounting Association.

Mc Enroe, John E., \& Pitman, Marshall K. (2003). An analysis of the accounting profession's oligarchy: The auditing standards board. Research in Accounting Regulation, 16: 29-44.

Miller, D.L. (1997). One Strategy for Assessing the Trustworthiness of Qualitative Research: Operationalizing the External Audit. Paper Presented at the Annual Meeting of the American Educational Research Association, Chicago, IL.

Ponemon, L. A. \& Gabhart, D. R. L. (1990). Auditor Independence Judgments: A Cognitive Developmental Model and Empirical Evidence'. Contemporary Accounting Research, 7(1), 227-251.

Porter, B. (1997). Auditors' responsibilities with respect to corporate fraud: a controversial issue. In Sherer, M. and Turley, S. (Eds), 3rd ed., Current Issues in Auditing, Paul Chapman Publishing, London, Ch. 2, pp. 31-54. 
Rasmussen, B.W. \& Windsor, C. A. (2003). Danish Evidence of Auditors' Level of Moral Reasoning and Predisposition to Provide Fair Judgements. Journal of Business Ethics, 47: 77-87.

Sarens, Gerrit. \& De Beelde, Ignace (2006). The Relationship between Internal Audit and Senior Management: A Qualitative Analysis of Expectations and Perceptions. International Journal of Auditing, 10: 219-241.

Sawyer, L.B. (1988). Sawyer's Internal Auditing. The Institute of Internal Auditors, Altamonte Springs, FL.

Schlenker, B. (1997). Personal responsibility: Applications of the Triangle Model. Research in Organizational Behavior, 19: 241-301.

Shih, Kuang-Hsun.Chen, Hsueh-Ju. Chen. \& Jason C.H. (2006). Assessment of sustainable development and knowledge of environmental management: Internal auditors' perspectives. Industrial Management \& Data Systems, 106(6): 896-909.

Sikka, P. Filling, S., \& Liew, P. (2009). The audit crunch: reforming auditing. Managerial Auditing Journal, 24(2): 135-155.

Sutton, M.H. (2002). Financial reporting at a crossroads. Accounting Horizons, 16(4).

Uecker, W. C., Brief, A. P. \& Kinney, W. R. (1981). Perception of the internal and external auditor as a deterrent to corporate irregularities. The Accounting Review, $\operatorname{LVI}(3)$.

Van Peursem, Karen. (2004). Internal auditors' role and authority: New Zealand evidence. Managerial Auditing Journal, 19(3): 378-393.

Wallace, W. (1984). A Time Series Analysis of the Effect of Internal Audit Activities on External Audit Fees. Altamonte Springs, FL: Institute of Internal Auditors.

Warming, Rasmussen. (1996). God Revisoradfærd - et spørgsmål om reguleringeller moral ogetik?.INSPI 12: 33-38, København.

Yakhou, Mehennai. \& Dorweiler, Vernon P. (2004). Dual reforms Accounting and corporate governance. Managerial Auditing Journal, 19(3). 